\section{The incidence of post- operative nausea and vomiting in women undergoing laparoscopy is influenced by the day of menstrual cycle}

W. Scott Beattie MD PhD FRCPC, Trinsa Lindblad MD, D. Norman Buckley MD FRCPC, James B. Forrest MB ChB PhD FRCPC
Postoperative nausea and vomiting is a major cause of postoperative morbidity. It can lead to increased recovery time, delaying patient discharge and an increase in hospital costs. Past studies have shown that postoperative nausea and vomiting is more frequent in women than men, appears to elevate around the time of menarche and is reduced around the time of menopause. This retrospective review of a one-year experience of laparoscopic tubal ligation at our institute examined the effect of menstrual cycle on postoperative nausea and vomiting. The anaesthetic and surgical techniques were consistent for all patients. Patient data included age, weight, last day of menstrual cycle, the length of anaesthesic, the dose of inhalational agent, the dose of narcotic, emesis on emergence and whether or not droperidol was used. Of the the 235 patients in the study, the incidence of nausea and vomiting was $28 \%$. One hundred fifty-eight had had no preoperative antiemetic and 77 had received droperidol. These two groups were analyzed separately. The incidence in the group not receiving droperidol was $33.5 \%$ and in the droperidol group, $16.9 \%(P<0.01)$. The incidence of nausea and vomiting was higher on the first eight menstrual days (51.6 vs $21.6, P<0.001)$, was highest on day five of the menstrual cycle and lowest on days 18, 19, and 20 where there was no nausea and vomiting. Droperidol reduced the incidence of postoperative nausea and vomiting but the variation in posloperative nausea and vomiting during the cycle persisted. These data suggest that the scheduling of laparoscopy according to menstrual cycle may be more effective than

\section{Key words}

vOMITING: antiemetics, incidence, nausea.

From the Department of Anaesthesia, McMaster University, 1200 Main Street West, Hamilton, Ontario L8N $3 Z 5$.

Presented at the C.A.S. Annual Mecting, Ottawa, Ontario, Canada, June 1989

Address correspondence to: $\mathrm{Dr}$. W. Scott Beattie. Accepted for publication 30th November 1990. droperidol alone in reducing postoperative nausea and vomiting. The relative risk of nausea and vomiting is four times greater during menses.

Le vomissement et nausée postopératoires sont une cause majeure de morbidité postopératoire. Ils peuvent occasionner une augmentation du temps de récupération, retarder le congé du patient et augmenter le coût de l'hospitalisation. Des érudes antérieures ont démontré que la nausée et vomissement sont plus fréquents chez les femmes plutôt que les hommes, l'incidence augmentant autour du temps de la ménarche et diminuant autour du temps de la ménaupose. Celte revue rétrospective d'une expérience d'un an de ligature rubaire par laparoscopie dans notre Institut examine les effets du cycle menstruel sur la nausée et vomissement postopératoires. Les techniques anesthésiques et chirurgicales étaient identiques pour toutes les patientes. Les données des patientes incluaient l'âge, le poids, le dernier jour de cycle menstruel, la durée de l'anesthésie, la dose des agents d'inhalation, la dose de narcotique, le vomissement à l'émergence et l'utilisation du dropéridol. Des 235 patientes de l'étude, l'incidence de nausée et vomissement était de 28\%. Cent cinquante-huit patientes n'avaient reçu aucun antiémétique en période préopératoire es 77 patientes avaient reşu du dropéridol. Ces deux groupes furent analysés séparément. $L$ 'incidence dans le groupe n'ayant pas reçu de dropéridol était de $33.5 \%$ et celle du groupe dropéridol, $16.9 \%(P<0.01)$. $L$ 'incidence de nausée et vomissement était plus élevée dans les huit premiers jours de la menstruation (5l.6 versus $21.6, P<$ $0.001)$. Cette incidence atteignait un maximum au cinquième jour du cycle menstruel et un minimum au jour 18,19, et 20 où on observa ni nausée ni vomissement. Le dropéridol a réduit l'incidence de nausée et vomissement postopératoires mais les variations postopératoires de la nausée et vomissement durant le cycle persistèrent. Ces données suggèrent que la cédule de la laparoscopie, dépendamment du cycle menstruel, pourrait être plus efficace que le dropéridol seul, afin de réduire l'incidence de nausée et vomissement postopératoires. Le risque relatif des 
nausées et vomissements est quatre fois plus grand duram les menstruations.

Nausea and vomiting is a common cause of postoperative morbidity. ${ }^{1,2}$ It may prolong recovery time, delay patient discharge and increase hospital costs. The incidence of postoperative nausea and vomiting is influenced by the site and duration of surgery, anaesthetic agents and sex. Indeed, the incidence of postoperative nausea and vomiting is two to three times higher in females than males. ${ }^{2}$ Vomiting increases as girls approach menarche ${ }^{3}$ and the incidence in postmenopausal females is similar to that of men $^{4}$ suggesting a major hormonal influence. A recent report showed that hormonal status may influence the incidence of nausea and vomiting. ${ }^{5}$ We postulated that the incidence of postoperative nausea and vomiting would vary with the day of the menstrual cycle. The present study examined retrospectively the incidence of nausea and vomiting for each day of the menstrual cycle and the effect that droperidol had on reducing nausea and vomiting throughout the menstrual cycle.

\section{Methods}

The charts of all cases referred to our institution for laparoscopic tubal ligation from July 1, 1987 to June 30, 1988 were reviewed. Since our main hypothesis dealt with women having normal menstrual cycles, all patients who were pregnant, on birth control pills, were postpartum (and who had not experienced a menstrual cycle since delivery) or who did not know the date of their last menstrual period were excluded from analysis. These were the only exclusion criteria.

The anaesthetic and surgical techniques were consistent for all patients. Individual anaesthetists gave droperidol according to individual practice. None of the patients was premedicated. An iv line was started in the operating room. Prior to induction of anacsthesia each patient received $1.0-2.5 \mu \mathrm{g} \cdot \mathrm{kg}^{-1}$ fentanyl, and $3-4.5 \mathrm{mg}$ d-tubocurarine. Induction consisted of thiopentone 4-6 $\mathrm{mg} \cdot \mathrm{kg}^{-1} i v$, succinylcholine $1.0-1.5 \mathrm{mg} \cdot \mathrm{kg}^{-1}$. After placement of a tracheal tube the lungs were ventilated with a tidal volume $10 \mathrm{ml} \cdot \mathrm{kg}^{-1}$ at a rate of 12 breaths per minute. Maintenance of anaesthesia was with $\mathrm{N}_{2} \mathrm{O}$ and $\mathrm{O}_{2}$ $\left(\mathrm{FlO}_{2}\right.$ of $\left.30 \%\right)$ and isoflurane (or equivalent) at an inspired concentration of $1-1.5 \%$ delivered through a Mapleson D circuit (Table I). Muscle relaxation was maintained with either vecuronium or atracurium. Tubal ligation was performed in all cases of laparoscopy with intraabdominal $\mathrm{CO}_{2}$ and the patients in steep Trendelenburg position. Muscle relaxation was reversed with neostigmine $40 \mu \mathrm{g} \cdot \mathrm{kg}^{-1}$ and glycopyrrolate $7 \mu \mathrm{g} \cdot \mathrm{kg}^{-1}$. Neither the decision to give droperidol nor its dose was controlled.
TABLE I Anaesthetic and patient data

\begin{tabular}{llc}
\hline & Droperidol & No droperidol \\
\hline Number of patients & 77 & 158 \\
Age & 33 & 33 \\
Weight $(\mathrm{kg})$ & 63 & 64 \\
Anacsthcsia & & \\
- Fentanyl $\left(\mu \mathrm{g} \cdot \mathrm{kg}^{-1}\right)$ & 1.28 & 1.25 \\
- $\mathrm{N}_{2} \mathrm{O} \%$ & 70 & 70 \\
- isoflurane \% & $<1.5[69]$ & $<1.5[142]$ \\
- Halothanc \% & $<1.0[6]$ & $<1.0 \quad[13]$ \\
- Enflurane \% & $<1.5[2]$ & $<1.5 \quad[3]$ \\
- Duration (min) & 32 & 27 \\
\hline
\end{tabular}

[ ] Number of Patients.

In all patients tubal interruption was achieved with clip or rings. No patient had cautery to induce tubal occlusion.

\section{Patient data}

Patient data included age, weight, day of last menstrual cycle, duration of anaesthetic, dose of inhalational agent, the dose of narcotic, emesis on emergence and dose of droperidol. The incidence of postoperative nausea and vomiting was determined from the nursing assessment in the PAR or from the nurse's assessment in the Short Stay Unit (where all outpatients are observed for two to four hours after general anaesthesia) before discharge. Records were examined for the presence or absence of nausea and vomiting.

\section{Statistics}

Analysis of variance and non-paired $t$ test were used to compare patient characteristics where appropriate. Chi squared analysis was used to compare proportions and the incidence of nausea and vomiting. A $P$ value of 0.05 was considered significant.

\section{Results}

A total of 350 charts was reviewed. One hundred and fifteen patients met exclusion criteria. Of the 235 patients remaining in the study, 158 had no preoperative antiemetic and 77 had received droperidol. These two groups were analyzed separately. The overall incidence of postoperative nausea and vomiting was $28 \%$. The incidence in the group not receiving droperidol was $33.5 \%$ and in the droperidol group, $16.9 \%(P<0.01)$.

We found a much higher incidence of vomiting early in the menstrual cycle (Figure 1). The incidence of postoperative nausea and vomiting peaked on day five at $80 \%$ $(8 / 10)$ and decreased to $25 \%(2 / 8)$ on day nine. The temporal distribution of postoperative nausea and vomiting in patients receiving droperidol is similar to those not receiving antiemetic; i.e., the incidence is higher early 


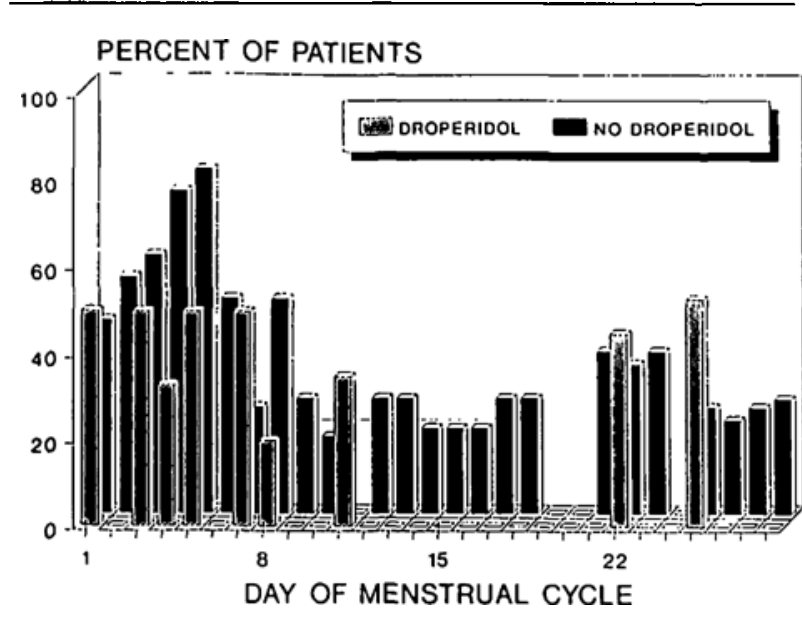

FIGURE 1 The incidence of nausea and vomiting by day of menstrual cycle. Solid bars represent patients with no antiemetics and open bars represent patients receiving droperidol.

after menses. Consequently, we examined the patients by phase of the menstrual cycle (days one to eight as preovulatory; days 9-16 as ovulatory; and days 17 to end of cycle as postovulatory). Statistical analysis confirmed the null hypothesis that the ovulatory and postovulatory periods were not different statistically. These were then pooled for a comparison of menses (pre-ovulatory) and after menses (day nine to end of cycle). All four groups were similar with respect to age, weight, dose of fentanyl, use of inhalational agent and duration of anaesthetic. There was more postoperative nausea and vomiting in the menses group than the after menses group for both the group receiving droperidol and the group receiving no antiemetic. This represented a four-fold increase in the relative risk of postoperative nausea and vomiting if the procedure was performed during menses $\left(P=3 \times 10^{-4}\right)$ (Table II). For both the droperidol group and the group receiving no antiemetic, there is a significant effect of time of menstrual cycle. However, the comparison between the patients receiving no antiemetic with those receiving droperidol in the "menses" and "after menses" groups did not achieve statistical significance. Examination of the dose response for droperidol in these two groups found that the dose of droperidol necessary to decrease postoperative nausea and vomiting is greater in

TABLE II Risk reduction menses/after menses

\begin{tabular}{llc}
\hline & Droperidol & No droperidol \\
\hline Relative risk & 4.8 & 3.7 \\
Chi square & 5.1 & 13.0 \\
$P$ & 0.02 & 0.001 \\
\hline
\end{tabular}

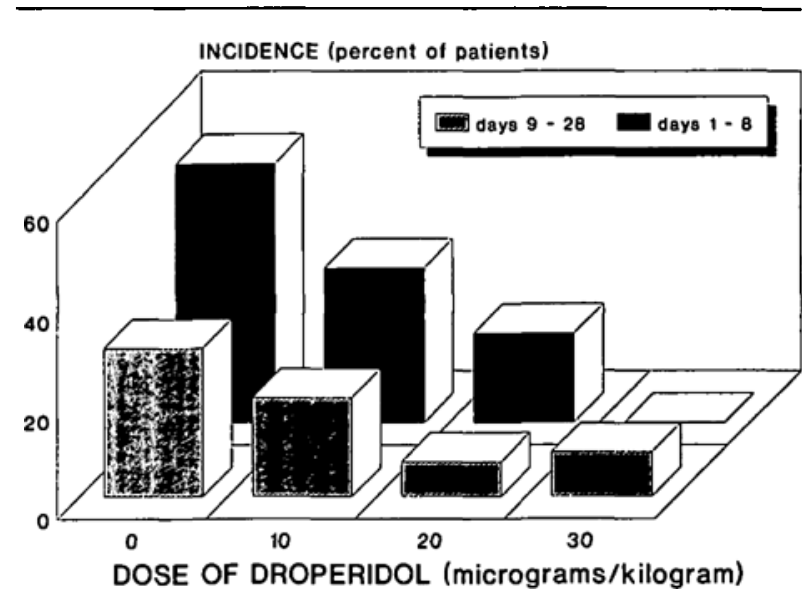

FIGURE 2 Dose response for droperidol. Incidence of nuusea and/or vomiting decreases as dose increases; however, significantly more women have postoperative nausca and/or vomiting for droperidol at doses of $0,10,20 \mu \mathrm{g} \cdot \mathrm{kg}^{-1}$ droperidol $P<0.05$.

the menses group than in the after menses group (i.e., the dose response curve is shifted to the right) (Figure 2).

\section{Discussion}

This report showed that nausea and vomiting varied with the day of the menstrual cycle. The relative risk of nausea and vomiting is four times greater during menses (days one to eight of the cycle). This finding is clinically important since simply rescheduling surgery may be more effective than any pharmacological manoeuvre in preventing nausea and vomiting. This study is flawed by being retrospective and by not strictly controlling the administration of the anaesthetic. Nevertheless, we feel our findings are important. The overall incidence of nausea and vomiting in patients not receiving an antiemetic $(33 \%)$ is similar to previous reports. ${ }^{6,10-12}$ Secondly, these results are consistent with previous reports where the incidence of nausea and vomiting seemed to vary with the hormonal milieu. ${ }^{5}$

The hormonal changes of the normal menstrual cycle are complex but there is little doubt about the influence on emesis. Leta ${ }^{3}$ showed higher rates of emesis in older children. As women approach menopause, the incidence decreases, approaching that of men. ${ }^{4}$ Patients having a D\&C are likely to have low levels of hormones with little fluctuation, as many are post-menopausal and, in fact, Pataky et $a l^{5}$ found a lower incidence of postoperative nausea and vomiting in patients undergoing $D \& C$ than in those undergoing laparoscopy and ovum retrieval. Hormone induction protocols cause the ovum retrieval patient to have very high oestrogen concentrations. The hormonal status of laparoscopy patients will vary with changes associated with the normal cycle. The results of the 
present study demonstrate the varying incidence of postoperative emesis throughout the menstrual cycle.

Hormonal influences, mostly oestrogen, have been implicated in other types of emetic syndromes. Hyperemesis gravidarum is thought to be due to the oestrogen-like compound $\mathrm{B} \mathrm{HCG}{ }^{6}$ Tamoxifen, a specific oestrogen receptor blocker, causes serum oestrogen levels to rise. ${ }^{7}$ Emesis occurs in 20 to $25 \%$ of patients taking tamoxifen and the addition of oestrogen to a chemotherapy regime to treat breast cancer increases nausea and vomiting to $50 \% .{ }^{8}$ Our hypothesis suggests that oestrogen acts at some receptor other than the oestrogen receptor to increase nausea and vomiting. However, it is not simply the level of oestrogen which is important.

The high incidence of postoperative nausea and vomiting on day five does not correlate with peak levels of $\mathbf{L H}$, FSH, oestrogen or progesterone. However, beginning on about day five, oestrogen levels begin to rise and FSH levels begin to fall. We postulate that changing concentrations of FSH and/or oestrogen may sensitize the chemoreceptive trigger zone and/or the vomiting centre. This in turn may predispose the patient to postoperative nausea and vomiting when exposed to the added stimulus of surgery and/or anaesthesia.

The role of droperidol is intriguing. Droperidol acts to inhibit postsynaptic dopamine receptors. ${ }^{9}$ The reason for the efficacy of droperidol in reducing postoperative nausea and vomiting is not clear. Pandit ${ }^{10}$ demonstrated a reduction in the incidence of postoperative nausea and vomiting with droperidol. He suggested a dose of 10-20 $\mu \mathrm{g} \cdot \mathrm{kg}^{-1}$ as being most efficacious. Williams ${ }^{11}$ in a blinded study assessing several methods of decreasing postoperative nausea and vomiting showed no difference between placebo and droperidol $15 \mu \mathrm{g} \cdot \mathrm{kg}^{-1}$ on the incidence of postoperative nausea and vomiting. Young et al. ${ }^{12}$ showed no difference between droperidol 20 $\mu \mathrm{g} \cdot \mathrm{kg}^{-1}$ and a placebo. In our patient population, droperidol reduced the incidence of postoperative nausea and vomiting. However, the reduction of postoperative nausea and vomiting attributed to droperidol did not achieve statistical significance in either the menses or the after menses group. This suggests that the scheduling of surgery with respect to time of menstrual cycle would be more effective in reducing the incidence of postoperative nausea and vomiting than the use of droperidol. A possible explanation for this apparent lack of efficacy of droperidol is an inadequate dose. We have compared the dose response curve for the menses and after menses group. The dose response relationship is shifted to the right in the menses group suggesting that twice as much droperidol is required around the time of menses in order to be an effective antiemetic.

Since droperidol acts on dopamine receptors, the shift in the dose response relationship suggests an alteration in the sensitivity of dopamine receptors. The precise nature of this interaction awaits further investigation. However, oestrogen has been shown to increase the number of dopamine receptors. ${ }^{13}$ The results of our study have important clinical implications. The scheduling of surgery with consideration to the day of the menstrual cycle may serve to reduce the incidence of postoperative nausea and vomiting. The use of droperidol in appropriate doses in relation to the menstrual cycle may also be an important therapeutic modality. However, the most effective dose is unknown. The results show the need to account for menstrual variations in any further trial which assess efficacy of antiemetics.

\section{Acknowledgements}

The authors would like to thank Mrs. Valerie Cannon and Miss Joanne Taylor for their secretarial assistance in preparing the manuscript.

\section{References}

1 Palazzo MGA, Strunin L. Review article: anacsthesia and emesis. I: Etiology. Can Anaesth Soc J 1984; 31 178-87.

2 Palazzo MGA. Strunin L. Review article: anacsthesia and emesis II: Prevention and management. Can Anaesth Soc J 1984; 31: 407-15.

3 Rita L, Goodarzi M, Seleny $F$. Effect of low dose droperidol on postoperative vomiting in children. Can Anacsth Soc J 1981; 28: 259-62.

4 Forrest JB, Cahalan MK, Rehder $K$ et al. Multicenter study of general anesthesia. 11. Results. Anesthesiology 1990; 72: 262-8.

5 Pataky $A O$, Kitz DS, Andrews RW, Lecky $J H$. Nausca and vomiting following ambulatory surgery: are all procedures created equal? Anesth Analg 1988; 67: S163.

6 Kauppila A, Huhtanieme E, Ylikorkala $O$. Raised scrum HCG concentrations in hyperemesis gravidarum. BMJ 1979; 1: 1670-1.

7 Pommier RF, Woltering EA, Keenan EJ, Fletcher WS. The mechanism of hormone-sensitive breast cancer progression on antiestrogen therapy. Arch Surg 1987; 122: 1311-6.

8 Benz $C$, Gandara $D$, Miller $B$ et al. Chemoendocrine therapy with prolonged estrogen priming in advanced breast cancer: endocrine pharmacokinetics and toxicity. Cancer Treat Rep 1987; 71 : 283-9.

9 Stoelting $R K$. Drugs used in treatment of psychiatric disease. In: Stoelting RK (Ed.). Pharmacology and Physiology in Anesthetic Practice, Philadelphia: JB Lippincott, 1987; 347-64. 
10 Pandit SK, Kothary SP, Pandit UA. Antiemetic efficacy of oral metoclopramide versus intravenous droperidol for outpatient laparoscopic procedures. Ancsthesiology 1987; 67: A425.

11 Williams JJ, Goldberg ME, Larijani GE et al. A blinded prospective comparison of different methods of reducing nausea and/or vomiting after out-patient surgery. Anesthesiology 1988; 69: A907.

12 Young ML, Kitz DS, Andrews R, Lecky JH, Conahan $T J$. Efficacy of anticmetic prophylaxis in patients receiving general anaesthesia for outpatient surgery. Anesthesiology 1988; 69: A449.

13 Hruska RE, Silbergeld EK. Increased dopamine receptor scnsitivity after estrogen treatment using the rat rotation model. Science 1980; 208: 1466-7. 